\title{
GOD AND HUMANITY IN AUSCHWITZ
}

For decades, scholars have been investigating the historical role of Christianity in reinforcing and enhancing anti-Semitism in Western civilization. ${ }^{1}$ Analyses have focused as well on evaluating the meaning of the scriptural texts in light of the Holocaust. Ongoing debates have also swirled around the single, dual, and multicovenantal theories, the exact role of the Pharisees at the time of Jesus and thereafter, the meaning of those enigmatic chapters, Romans 9-11, and the search for a nontriumphalistic Christology. ${ }^{2}$ These scholarly analyses and debates indicate a healthy reevaluation of the meaning of Christianity and the ongoing Jewish-Christian relationship.

One of the fundamental debates has centered on redefining the human condition in the context of the post-Shoah society. Our experience from 1933 to 1945 has profoundly altered our understanding of the foundation of the moral values that can safeguard human existence. While modernity viewed as a rationalizing and sociological phenomenon provided the Nazis with the political, social, economic, and psychological tools to wreak disaster, the Christian tradition of political adaptation played a pivotal role as well. Significantly, Nazi ideologists sought to transform earlier theological concepts into anthropological and political constructs. ${ }^{3}$

Scholarly debates have increasingly been centering on the individual's relationship to God and on the formation of moral values that can combat sanctioned massacre. Protestant ${ }^{4}$ and Catholic theologians have also responded to the Holo-

'See Rosemary Ruether, Faith and Fratricide (New York: Seabury Press, 1974); John Gager, The Origins of Anti-Semitism: Attitudes toward Judaism in Pagan and Christian Antiquity (New York: Oxford University Press, 1983); Elisabeth Schüssler Fiorenza and David Tracy, eds., The Holocaust as Interruption (Edinburgh: T.\&T. Clarke, 1984).

${ }^{2}$ See John Pawlikowski, "Christian Ethics and the Holocaust: A Dialogue with PostAuschwitz Judaism," Theological Studies 49 (1988) 649-99; Anthony Saldarini, "Delegitimation of Leaders in Matthew 23," Catholic Biblical Quarterly 54 (1992) 659-80.

${ }^{3}$ Zygmunt Bauman, Modernity and the Holocaust (Ithaca: Cornell University Press, 1989); Uriel Tal, "Forms of Pseudo-Religion in the German Kulturbereich Prior to the Holocaust," Immanuel 3 (1973-1974) 69; Ervin Staub, The Roots of Evil: The Origins of Genocide and Other Group Violence (Cambridge, 1989).

${ }^{4}$ A. Roy Eckardt, Jews and Christians: The Contemporary Meeting (Bloomington: Indiana University Press, 1986); Franklin H. Littell, The Crucifixion of the Jews (New 
caust, out of necessity, since it was Christian theology that legitimated antiSemitism in our culture. Christians have to accept a part of the responsibility for Auschwitz. Because of its centralized ecclesial structure as well as cultural reliance on dogmatic and systematic theology, Catholics responded more slowly to the theological implications of modernity and the Holocaust. Vatican II and Nostra Aetate (1965), however, accelerated the responses.

Historically, the transcendent eschaton in Christian theology has, at least in Catholic theology, encouraged a privatized theology remote from the brutalized world of marching soldiers. Until Vatican II, Catholic speculative and moral theology have tended to be ahistorical or have striven to promote adaptation to the "evil" world, both to ensure the continuance of the Church as an institution and to support a "common good" free from violence. ${ }^{5}$ Hans Küng has referred to this dilemma. "The Church, being of men, is forever under the temptation to make herself at home in the world, to regard her worldly successes as the coming of the kingdom of God, to be intent only on making herself secure and powerful and free from opposition and persecution." The Church, it can be argued, is in the world to preach the word of God, to continue the work of Christ, and to be a moral force. But this same Church historically has also been an institution interested in self-preservation and an extension of clerical influence to enhance the Church's mission as an instrument of salvation. To help resolve secular conflicts, the Church has generally relied upon the theory of natural law, which can most simply be defined as an unwritten law of morality that is ascertainable by sound human reason. Natural law, however, is abstract and vague to the point of making its application to concrete cases extremely difficult. ${ }^{7}$ It is not governed by the event.

Rooted in natural law and the model of private confession, the Christian moral tradition historically has stressed individual responsibility, private penance, and the exposure of personal motivations. But until recently it has not done well with the concept of collective responsibility for significant sociopolitical issues. The traditional presumption in moral theology, for example, has been that in evil or sinful acts the number of participants is usually small and that total responsibility can only be legitimately assigned to a few discrete individuals who are "guilty." A social justice theory, therefore, emerged, in which the influence of confession as such ultimately led to a concentration on individuals and a reluc-

York: Harper \& Row, 1975; ROSE ed.: Macon GA: Mercer University Press, 1986); Robert Osborn, "The Christian Blasphemy," Journal of the American Academy of Religion 53 (1985) 339-63.

${ }^{5}$ Donald J. Dietrich, Catholic Citizens in the Third Reich: Psycho-Social Principles and Moral Reasoning (New Brunswick NJ: Transaction Press, 1988).

${ }^{6}$ Hans Küng, The Council: Reform and Reunion (New York: Sheed \& Ward, 1961).

${ }^{7}$ Encyclical Summi Pontificatus, 20 October 1939, International Conciliation, no. 355 (December 1939) 558. 
tance to "exonerate" them or mitigate the circumstances by recognizing a more socially or historically nuanced meaning of $\sin$ as it has permeated specific institutions or even the social and cultural underpinnings of society itself. As Christian theorists have faced the post-Holocaust world of political brutalization, intensifying racism, and ethnocentrism or xenophobia, the traditional Christian stress on an individual moral praxis not surprisingly has failed to adapt its cognitive and moral values to macroethical issues. A natural law "ideology critique" has not provided a useful tool that could allow moral theologians to participate in reconfiguring society. ${ }^{8}$ For example, until Vatican II the Holocaust did not have any historical impact on theology, aside from official pronouncements.

Among contemporary moral theologians, there now seems to be an emerging dissatisfaction with viewing "nature" as the conceptual abstraction responsible for delineating historical and moral parameters. This has contributed over the last few decades to the focus of moral attention moving from "human nature" to "human person" or "human dignity." The Council Fathers, for example, certainly were familiar with the whole moral tradition growing from the law of nature when they asserted that moral standards should be based on the "dignity" of the human person and then offered reflections in Gaudium et Spes on the implications that stem from that standard. Stress on the person with this intrinsic integrity has become the principle criterion of the morally right and wrong act. In the process of moral deliberation, historical experience is now playing an indispensable role. Sin is no longer seen as merely an isolated act of an individual, but rather has institutional and structural dimensions as well. Hence, the sins of one generation can become subsequent limiting conditions. ${ }^{9}$

This holistic approach to the individual person critiques any consideration and comparison of moral values in remote abstraction from the totality of lived experiences. The salubrious result has been that moral norms, which in the past have been articulated in the conceptual analysis of human metaphysical nature into religious, physical, and property values, is now yielding to a hierarchy of urgencies. ${ }^{10}$ Central to feminist, liberation, political, and Holocaust theologies, for example, is their return to history and their acknowledgment of the rupture or break from the world of suffering, the focus on liberation over easy announcements of reconciliation, the retrieval of the social systemic of sin in place of simply listing individual sins, and the insistence on the concrete praxis of

${ }^{8}$ John Mahoney, The Making of Moral Theology: A Study of the Roman Catholic Tradition (Oxford: Clarendon Press, 1989) 32-35, 333-34.

${ }^{9}$ Gaudium et Spes, no. 51, Acta Apostolica Sedis 58 (1966) 1072; John XXIII, Pacem in Terris (New York, 1963) 8-9; Richard McCormick, "Moral Theology, 1940-1989: An Overview," Theological Studies 50 (1989) 16, 19.

${ }^{10} \mathrm{~J}$. M. Aubert, "Hierarchi• de valeurs et histoire," Revue des Sciences Religieuses 44 (1970): 5-22; John Harris, The Value of Life (London: Routledge and Kegan Paul, 1985); Mahoney, The Making of Moral Theology, 318-19. 
discipleship. If Christian theology is to enter history, then surely the Holocaust interruption can be seen as a frightening disclosure of the real history of the species. Christian theology cannot fully return to history until it faces this cataclysmic event. ${ }^{11}$

Reflecting on the Holocaust as well as on other sanctioned murders has helped theologians sharpen their focus on a God-human relationship that can pass the reality test of connecting morality and politics. They have increasingly rejected micromorality with its rigid categorist thinking, with its theology not fully consonant with the Scriptures, and with its anthropology not emanating from an authentic concept of the personal dignity of the individual or the sanctity of human interrelationships. At this point, Christians have generally accepted their complicity in sociopolitical evil and have begun to posit remedies that can respond to historical data. In theology, this has been labeled "ideology critique." The goal of this critique is to reappropriate the authentic Christian message so that it can prove as meaningful today as it did to the first Christians. ${ }^{12}$

DONALD J. DIETRICH Boston College Chestnut Hill, Massachusetts

\footnotetext{
"Johannes Baptist Metz, "Facing the Jews: Christian Theology after Auschwitz," 2633, and Gregory Baum, "The Holocaust and Political Theology," 34-42, are both in Schüssler Fiorenza and Tracy, eds., The Holocaust as Interruption.

${ }^{12}$ Gregory Baum, "The Holocaust and Political Theology," in Schüssler Fiorenza and Tracy, eds., The Holocaust as Interruption, 36; Donald J. Dietrich, God and Humanity in Auschwitz: Jewish-Christian Relations and Sanctioned Murder (New Brunswick NJ: Transaction Press, 1995); Matthew Lamb, Solidarity with Victims: Toward a Theology of Social Transformation (New York: Crossroad, 1982).
} 